\title{
Does Ozone Administration Have a Protective Effect Against Cisplatin- induced Histological Changes in Rat Testis?
}

\author{
Cisplatine Bağlı Rat Testisinde Meydana Gelen Histolojik Değişikliklere Karşı Ozon \\ Tedavisinin Koruyucu Bir Etkisi Var mıdır?
}

\author{
(D) İbrahim Aydoğdu1, (D) Rahmi Gökhan Ekin2, (D) Pelin Yıldız3, (D) Semih Lütfi Mirapoğlu11, (D) Ali Çay1, (D) Yaren Ece Aydoğdu4, \\ (D) Hüseyin Kılınçaslan5, (D) Mehmet Bülent Semerci6, (D) Yusuf Özlem İlbey² \\ ${ }^{1}$ Bezmialem Vakıf University Faculty of Medicine, Department of Pediatric Surgery, istanbul, Turkiye \\ 2 University of Health Sciences, Izmir Tepecik Training and Research Hospital, Clinic of Urology, Izmir, Turkiye \\ 3Bezmialem Vakıf University Faculty of Medicine, Department of Pathology, Istanbul, Turkiye \\ ${ }^{4}$ Bezmialem Vakıf University Faculty of Medicine, Istanbul, Turkiye \\ 5 Avrasya Hospital, Clinic of Pediatric Surgery, Istanbul, Turkiye \\ ${ }^{6}$ Ege University Faculty of Medicine, Department of Urology, Izmir, Turkiye
}

What's known on the subject? and What does the study add?

There is currently no study of the protective effect of ozone treatment against cisplatin-induced testicular damages.

\begin{abstract}
Objective: We investigated the protective and therapeutic effects of ozone therapy (OT) on cisplatin (CP)-induced testicular damage.

Materials and Methods: Thirty healthy adult male Wistar rats were divided into five groups consisting of 6 animals each: 1) control, 2) $\mathrm{CP}_{1}$ 3) OT, 4) $\mathrm{OT}+\mathrm{CP}$ and 5) CP + OT groups. Histopathological findings, Johnsen scores, thiobarbituric acid-reactive substances (TBARS), glutathione (GSH), superoxide dismutase (SOD), catalase, and GSH peroxidase (GPx) levels were evaluated.

Results: $\mathrm{CP}$ caused a significant decrease in testicular weight and Johnsen score compared to the control group. In addition, TBARS level was significantly higher, whereas GSH, SOD, catalase and GPx levels were significantly lower in the CP group when compared to the control group. Pre- and post-CP OT significantly increased GSH, SOD, catalase and GPx levels and decreased TBARS level. Also, testicular weight and Johnsen score were increased with OT.

Conclusion: The present study showed that OT is protective against CP-induced testicular damage. OT may be beneficial to patients who underwent CP chemotherapy.
\end{abstract}

Keywords: Ozone therapy, Cisplatin, Chemotherapy, Testicular histopathology, Testis

Öz

Amaç: Bu çalışmada, ozon tedavisinin (OT) cisplatin tedavisine (CT) bağlı gelişen testis hasarını önleyici ya da tedavi edici etkisini araştırdık.

Gereç ve Yöntem: Wistar cinsi 30 sağlıklı yetişkin erkek rat, her biri 6 rattan oluşan 5 gruba ayrıldı: 1) Kontrol, 2) CT, 3) OT, 4) OT + CT ve 5) CT + OT grubu. Histopatolojik bulgular, Johnsen skorları, tiyobarbitürik asit reaktif maddeler (TBARM), glutatyon (G), süperoksit dismutaz (SOD), katalaz, G peroksidaz (GP) düzeyleri değerlendirildi.

Bulgular: CP grubu, kontrol grubuna kıyasla testis ağırlığında ve Johnsen skorunda belirgin bir düşüşe neden oldu. Ayrıca, TBARM düzeyi anlamlı derecede yüksek iken; G, SOD, katalaz ve GP düzeyleri CP grubunda kontrol grubuna göre anlamlı derecede düşük bulundu. CP + OT öncesi ve sonrası GSH, SOD, katalaz ve GP düzeylerini önemli ölçüde artırdı ve TBARM seviyesini düşürdü. Testikül ağırığı ve Johnsen skoru OT ile arttı.

Correspondence: İbrahim Aydoğdu MD, Bezmialem Vakıf University Faculty of Medicine, Department of Pediatric Surgery, İstanbul, Turkiye E-mail: draydogdu@yahoo.com ORCID-ID: orcid.org/0000-0001-7900-8598

Received: 02.08.2018 Accepted: 20.11.2018

Cite this article as: Aydoğdu İ, Ekin RG, Yıldız P, Mirapoğlu SL, Çay A, Aydoğdu YE, Kılınçaslan H, Semerci MB, İlbey YÖ. Does Ozone Administration Have a Protective Effect Against Cisplatin-induced Histological Changes in Rat Testis? J Urol Surg 2019;6(1):32-37.

Presented in: This study was presented at Scandinavian Association of Urology General Assembly at the NUF Congress, June 15th 2017, Odense, Denmark.

๑Copyright 2019 by the Association of Urological Surgery / Journal of Urological Surgery published by Galenos Publishing House. 
Sonuç: Bu çalışma, OT'un cisplatine bağlı gelişen testis hasarını önleyici etkisi olduğunu göstermiştir. OT, cisplatin uygulanan hastalarda testis hasarını önlemede yararlı olabilir.

Anahtar Kelimeler: Ozon tedavisi, Cisplatin, Kemoterapi, Testiküler histopatoloji, Testis

\section{Introduction}

One of the most effective chemotherapeutic drugs in the treatment of reproductive organs (ovary, testis), bladder, lung, head and neck cancers is cisplatin (CP) $(1,2)$. The curative effect is well known when $\mathrm{CP}$ is used alone or in combination with other drugs (3). On the other hand, CP has quite a lot of adverse effects, especially testicular toxicity that affects spermatogenesis, chromosomal abnormalities in spermatozoa and fertility. Due to these unwanted effects, clinical use of CP is limited most of the time (4). In many previous studies, it has been confirmed that CP that induces testicular oxidative stress had both short-term and long-term effects (5). Oxidative stress is usually held responsible for the pathogenesis of testicular damage after CP exposure (6). Therefore, anti-oxidants are widely recognized to guard rapidly dividing testicular cells against damage by $\mathrm{CP}(3,7)$.

Antioxidants are the natural defense mechanism against reactive $\mathrm{O}_{2}$ species (ROS) in most of the organs including the testicle. Oxidative damage occurs when there is a shift in the balance between production of ROS and the antioxidant defense mechanism in favor of ROS $(8,9)$. Ozone is an inorganic molecular colorless gas composed of three $\mathrm{O}_{2}$ atoms with a significant pungent odor at room temperature $(9,10,11)$. After ozone therapy (OT) administration, it dissolves in biological water and instantly reacts with antioxidant mechanisms. During these fast reactions, ozone is neutralized by activation of antioxidant mechanisms, which are superoxide dismutase (SOD), catalase, and glutathione (GSH) peroxidase (GPx) (11). The stimulation of endogenous antioxidants prepares the host defense against ROS $(9,10,11)$. The other important effects of ozone are immune modulation, neoangiogenesis and increased tissue oxygenation (11).

In the English literature, there is no previous study on the protective effect of ozone against CP-induced testicular injury. In this study, it was aimed to evaluate the effect of OT on testis histopathology before and after CP treatment in an experimental rat model.

\section{Materials and Methods}

The compatibility with ethical standards was provided using the experimental protocols for which the approval was officially taken from the local ethics committee on animal trials under the National Institutes of Health Guidelines for the Care and Use of Laboratory Animals. The approval was taken from Bezmialem Vakıf University Ethics Committee (number: 24.11.2015/237).

\section{Animals}

Thirty healthy adult male Wistar rats weighing between 245 and $310 \mathrm{~g}$ were used. The rats were kept in well-ventilated plastic cages at a room temperature of $25 \pm 3{ }^{\circ} \mathrm{C}$ and 12 -hour light/ dark cycle environment. Ad libitum feeding was applied with appropriate chow to laboratory conditions and potable water. The setting was acclimatized at one-week intervals.

\section{Experimental Design}

Thirty rats were randomly divided into 5 groups consisting of 6 animals each:

Group control: the rats received intraperitoneal $\mathrm{O}_{2}$,

Group OT: the rats were administered intraperitoneal OT to determine the effect of OT on testicular histopathology,

Group CP: the rats received a single dose of $7 \mathrm{mg} / \mathrm{kg}$ of CP intraperitoneally to determine the effect of $\mathrm{CP}$ on testicular histopathology as described by Beytur et al. (12),

Group CP + OT (CP after OT): the administration of a single dose of $7 \mathrm{mg} / \mathrm{kg}$ of CP was followed by intraperitoneal OT in order to determine the effect of OT on the histopathology of testicles of the rats undergoing $\mathrm{CP}$ chemotherapy,

Group OT + CP (OT after CP): the rats received intraperitoneal OT and then were administrated a single dose of $7 \mathrm{mg} / \mathrm{kg}$ of $\mathrm{CP}$ intraperitoneally to determine the effect of pre-CP chemotherapy OT on testicular histopathology.

All experimental procedures were performed under anesthesia by administering intraperitoneal $5 \mathrm{mg} / \mathrm{kg}$ xylazine hydrochloride and $50 \mathrm{mg} / \mathrm{kg}$ ketamine hydrochloride to the rats, then, the rats were immobilized by fixing them on the 4 corners of a tray.

\section{Ozone Therapy}

The ozone-oxygen mixture was produced by an ozone generator (Medozon Compact-Hab Herrmann Apparatebau, GmbH, Germany). The measured level for ozone concentration was found to be $254 \mathrm{~nm}$ on an ultraviolet spectrophotometer. The mixture included the ozone concentration measured at $50 \mu \mathrm{g} /$ $\mathrm{mL}$. Three-day administration of $0.2 \mathrm{mg} / \mathrm{kg} /$ day was made for the subjects to receive $10 \mu \mathrm{g} / \mathrm{mL}$ ozone. 


\section{Histopathological Examination}

Four days after the end of the experimental procedures, the rats were sacrificed by cervical dislocation, and bilateral orchiectomy was performed. The tunica albuginea was used to individually weigh testes. As described in a previous study, the left testis samples were examined by biochemical analysis and the right testis samples were examined histopathologically (10). Briefly, the samples were fixed in Bouin's solution and dehydrated in alcohol for 24 hours. After routine tissue processing, the samples were embedded in paraffin. Tissue sections $(3-\mu \mathrm{m}$ thick each) from the upper, lower and middle testicular regions were mounted for microscope slides. Staining cross-sections were provided using periodic acid-Schiff and hematoxylineosin under the standard protocols. The observation of the tissue slides was made through the standard light microscope by a pathologist, who was uninformed of the results, to apply experimental procedures. Calculation of the Johnsen scores was performed for each one. At least 50 tubules per tissue slide were examined and scored from 1 to 10 for each tissue slide according to spermatogenesis level (Table 1) (13).

\section{Biochemical Analysis}

A $10 \%$ homogenate of testicular tissue was prepared in $0.1 \mathrm{~mol} \mathrm{KCl}$ buffer ( $\mathrm{pH}$ 7.4) with Teflon-glass homogeniser. Following homogenization of the tissues, centrifugation was conducted at $18.000 \mathrm{~g}$ at $4{ }^{\circ} \mathrm{C}$ for $30 \mathrm{~min}$. To establish a lipid peroxidation index, Yagi's (14) method was effective to identify the levels of thiobarbituric acid-reactive substances (TBARS). The spectrophotometrical measurement was 532 $\mathrm{nm}$ for the absorbance level. The results for the tissues were in nmol g-1 tissue. The Sedlak and Lindsay (15) method was applied to obtain the GSH levels. Absorbance occurred at 412 $\mathrm{nm}$ as displayed by spectrophotometer, and the records were presented in nmol mL $\mathrm{mL}^{-1}$ tissue. The technique introduced by Sun et al. (16) provided with identifying the levels of SOD activity.

Table 1. The Johnsen score (13)

\begin{tabular}{ll}
\hline Score & Level of spermatogenesis \\
\hline 1 & No seminiferous epithelial cells, tubular sclerosis \\
\hline 2 & No germ cells, Sertoli cells only \\
\hline 4 & Spermatogonia only \\
\hline 5 & $\begin{array}{l}\text { Few spermatocytes, arrest of spermatogenesis at the } \\
\text { primary spermatocyte stage }\end{array}$ \\
\hline 6 & Many spermatocytes \\
\hline 7 & $\begin{array}{l}\text { Few early spermatids, arrest of spermatogenesis at the } \\
\text { spermatid stage }\end{array}$ \\
\hline 9 & No late spermatids, many early spermatids \\
\hline 10 & Less than five spermatozoa per tubule \\
\hline
\end{tabular}

In this method, inhibition of $\mathrm{O}_{2}$-induced nitroblue tetrazolium reduction, produced by the xanthine/xanthine oxidase system, is decisive. For one unit of SOD activity, the quantity of enzyme was used, which is necessary to result in the half-inhibition of nitroblue tetrazolium reduction rate at $560 \mathrm{~nm}$. The results in the study were expressed as IU $\mathrm{mg}^{-1}$ protein. Catalase activity was determined using the Aebi method (17). This method is based on the concept that catalase present in the sample converts $\mathrm{H}_{2} \mathrm{O}_{2}$ to $\mathrm{H}_{2} \mathrm{O}$ and $\mathrm{O}_{2}$. The spectrophotometrical measurement of $\mathrm{H}_{2} \mathrm{O}_{2}$ has decreased from $240 \mathrm{~nm}$. The results were displayed in $\mathrm{k} \mathrm{mg}^{-1}$ protein. The observations of the GPx activity levels were attained, thanks to the Paglia and Valentine's (18) method. This technique was established to match GPx activity and nicotinamide adenine dinucleotide phosphate oxidation using $\mathrm{GSH}$ reductase. The latter was spectrophotometrically measured at $340 \mathrm{~nm}$. The results were showed in IU $\mathrm{mg}^{-1}$ protein.

\section{Statistical Analysis}

The statistics were exhibited in the format of mean \pm standard deviation. The Kolmogorov-Smirnov test was used for normal distribution compatibility, and non-parametric tests of the Kruskal-Wallis and Mann-Whitney $U$ for between-groups analysis. Significance level was defined as $p<0.05$. Statistical analyses were conducted by SPSS package (version 19.0 for Windows; IBM, NY, USA).

\section{Results}

None of the rats in the study, performed on a total of 30 rats, died during the experiment. Histopathological examination and biochemical analysis were performed on the rats.

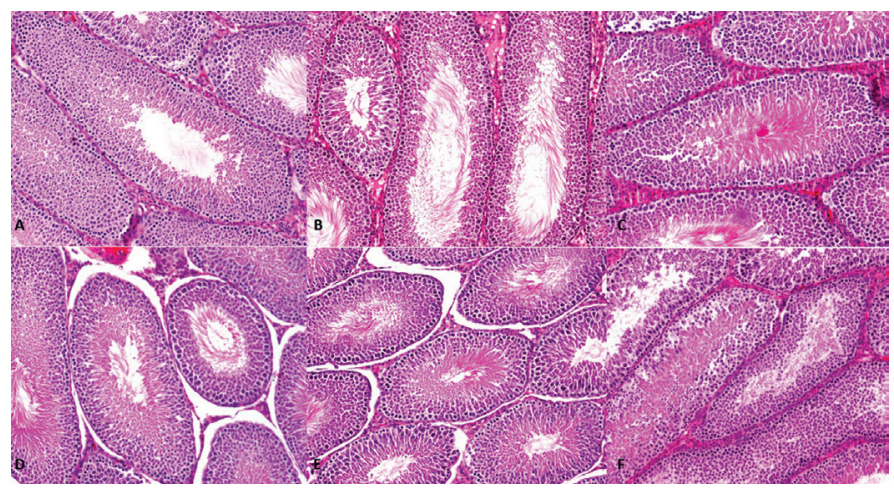

Figure 1. A) Normal testis histology (control group, hematoxylin and eozin, 100x), B) full spermatogenesis and normal testis histology (ozone therapy group, hematoxylin and eozin, 100x), C) necrosis of testicular tubules, impaired spermatogenesis (cisplatin group, hematoxylin and eozin, 40x), D) multinucleated giant cells in distributed testicular tubules (cisplatin group, hematoxylin and eozin, 40x), E) full spermatogenesis and normal testis histology (ozone theraphy + cisplatin group, hematoxylin and eozin, 100x, F) many early spermatids and disorganized epithelium (cisplatin + ozone theraphy group, hematoxylin and eozin, 100x) 
We observed significant testicular damage in the CP group (Table 2). The weight of both the right and left testicles in the $\mathrm{CP}$ group was significantly lower than in controls. But pre- and post-CP OT was significantly prevented this decreases caused by CP. In the control group, the rat testes showed normal morphology and spermatogenesis, healthy seminiferous tubules containing plenty of spermatids and sperm in the lumen (Figure 1). High Johnsen scores $(9.71 \pm 0.3)$ were detected in the control group. In the OT group, the rat testes showed mostly the same morphological characteristics as in the control group, but a few seminiferous tubules showed slightly impaired spermatogenesis. There was no significant difference in Johnsen score between OT and control groups $(9.64 \pm 0.2$ vs $9.71 \pm 0.3, p=0.833)$. In the $\mathrm{CP}$ group, the rat testes showed testicular interstitial fluid and interstitial edema, germ cell desquamation and irregular spaces in the epithelium, decreased spermatogenic cells and seminiferous tubules containing Sertoli cells and germ cell necrosis. The Johnsen scores were significantly decreased in the $\mathrm{CP}$ group compared to that in the control $(8.16 \pm 0.8$ vs $9.71 \pm 0.3$, $p<0.001)$ and OT $(8.16 \pm 0.8$ vs $9.64 \pm 0.2, p<0.001)$ groups. In the pre- and post-CP OT groups, the rat testes showed mild interstitial edema and tubules with incomplete maturation arrest. Spermatogenesis was maintained in the majority of the seminiferous tubules. The Johnsen scores were significantly increased in the $\mathrm{CP}+\mathrm{OT}$ and $\mathrm{OT}+\mathrm{CP}$ groups compared to that in the CP group $(9.54 \pm 0.3$ vs $8.16 \pm 0.8, p<0.001 ; 9.57 \pm 0.2$ vs $8.16 \pm 0.8, \quad p<0.001$, respectively). Meanwhile, no significant difference was found in Johnsen score between $\mathrm{CP}+\mathrm{OT}$ and control groups $(p=0.381), 0 T+C P$ and control groups $(p=0.377)$, and $\mathrm{CP}+\mathrm{OT}$ and $\mathrm{OT}+\mathrm{CP}$ groups $(\mathrm{p}=0.891)$.

Levels of TBARS, GSH, SOD, catalase and GPx in rat testis tissue are presented in Table 3. When the control group and CP group were compared in the testis tissues of the rat, the levels of TBARS were significantly higher in the CP group, whereas the GSH, SOD, catalase and GPx levels were significantly lower. On the other hand, pre- and post-CP OT caused a significant decrease in the TBARS level and an increase in GSH, SOD, catalase and $\mathrm{GPx}$ levels when compared to the CP group.

\section{Discussion}

It is well known that human testis is sensitive to CP. This study showed that $\mathrm{CP}$ chemotherapy induced significant damage in the testes of rats. Besides, pre- and post-CP OT was protective against spermatogenic cell damage.

$\mathrm{CP}$ is a highly effective anti-tumor drug used in the treatment of many different types of tumors, including testicular, ovarian, endometrium, cervical, bladder, lung and head and neck cancers. However, its usage is limited by its toxic effects on the reproductive system $(4,19,20)$. The main unwanted effects of $\mathrm{CP}$ are ototoxicity, nephrotoxicity, peripheral neuropathy, azoospermia, sperm morphology, and motility modifications $(19,21)$. As a result, prevention of side effects of CP is very important in terms of treatment protocol, benefits in quality of life and extending the limits of dose (4). CP targets testicular cell types such as Leydig cells, Sertoli cells and germ cells thus leading to male reproductive toxicity (22). In this research, testicular destruction induced simply by CP medication was seen as significant raises in lipid peroxidation, reduced antioxidant status and changed testicular histopathology in rats.

Oxidative stress plays a significant role in male reproductive dysfunction (23). Oxidative stress is an abnormal condition where the balance between the production of ROS and their adequate

Table 2. Comparison of testes weight and the Johnsen score among the five groups

\begin{tabular}{llllll}
\hline & Control & OT & CP & CP + OT & OT + CP \\
\hline Right testis weight $(g)$ & $1.321 \pm 0.05$ & $1.317 \pm 0.04$ & $0.868 \pm 0.03^{*}$ & $1.282 \pm 0.03^{\gamma}$ & $1.291 \pm 0.02^{\gamma}$ \\
\hline Left testis weight $(\mathrm{g})$ & $1.310 \pm 0.04$ & $1.308 \pm 0.03$ & $0.845 \pm 0.05^{*}$ & $1.289 \pm 0.03^{\gamma}$ & $1.287 \pm 0.03^{\gamma}$ \\
\hline Johnsen score & $9.71 \pm 0.3$ & $9.64 \pm 0.2$ & $8.16 \pm 0.8^{*}$ & $9.54 \pm 0.3^{\gamma}$ & $9.57 \pm 0.2^{\gamma}$ \\
\hline
\end{tabular}

ОТ: Ozone therapy, CP: Cisplatin, ${ }^{*}$ significantly different from the control group, ${ }^{\gamma}$ significantly different from the cisplatin group, data expressed as mean \pm standard deviation

Table 3. Comparison of thiobarbituric acid-reactive substances, glutathione, superoxide dismutase, catalase and glutathione peroxidase levels among the five groups

\begin{tabular}{llllll}
\hline & Control & OT & CP & CP + OT & OT + CP \\
\hline TBARS $\left(\mathrm{nmol} \mathrm{g}^{-1}\right.$ tissue) & $23.51 \pm 1.23$ & $24.86 \pm 3.12$ & $49.82 \pm 3.95^{*}$ & $25.63 \pm 3.88^{\gamma}$ & $24.90 \pm 4.13^{\gamma}$ \\
\hline GSH (nmol mL & $192.74 \pm 3.81$ & $194.41 \pm 4.22$ & $103.13 \pm 8.74^{*}$ & $187.04 \pm 4.15^{\gamma}$ & $190.07 \pm 5.99^{\gamma}$ \\
\hline SOD $\left(\mathrm{U} \mathrm{mg}^{-1}\right.$ protein) & $0.82 \pm 0.04$ & $0.80 \pm 0.04$ & $0.60 \pm 0.03^{*}$ & $0.79 \pm 0.03^{\gamma}$ & $0.78 \pm 0.04^{\gamma}$ \\
\hline Catalase $\left(\mathrm{k} \mathrm{mg}^{-1}\right.$ protein) & $2.43 \pm 0.81$ & $2.41 \pm 0.94$ & $1.23 \pm 0.45^{*}$ & $2.36 \pm 0.66^{\gamma}$ & $2.34 \pm 0.91^{\gamma}$ \\
\hline GPx $\left(\mathrm{U} \mathrm{mg}\right.$ mplein) $^{-1}$ prote & $220.11 \pm 26.52$ & $215.63 \pm 28.68$ & $151.18 \pm 28.40^{*}$ & $209.39 \pm 12.63^{\gamma}$ & $211.55 \pm 16.27^{\gamma}$ \\
\hline
\end{tabular}

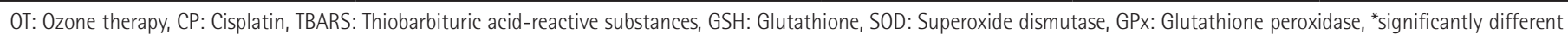
from the control group, ${ }^{\gamma}$ significantly different from the cisplatin group, data were expressed as mean \pm standard deviation 
elimination by antioxidant systems available in the body is severely disturbed $(4,19)$. Within pathological circumstances, ROS could be produced not merely by macrophages and neutrophils but likewise spermatozoa and various other cell types $(20,24,25)$.

$\mathrm{O}_{2}$ free radical formation is associated with impaired GSH metabolism, changes in the antioxidant enzymes, and lipid peroxidation $(4,20)$. Antioxidants are inactivating ROS and they maintain normal cell function $(8,9)$. The enzymes such as GPx, SOD and catalase are endogenous defense mechanisms that remove the activation of superoxide, hydrogen peroxide and hydroxyl radicals $(3,4,19,20)$. SOD changes superoxide anion in to water and $\mathrm{O}_{2}$, whilst catalase changes peroxide radicals in to water and $\mathrm{O}_{2}$. The reason for the decrease in enzymatic antioxidants is increased ROS production (8). TBARS are also a by-product of the damage that results from oxidative stress. TBARS produced from peroxidation of fatty acids by ROS are considered to be an indicator of lipid peroxidation (19). When there is a shift in the balance between the production of ROS and the antioxidant defense mechanism in favor of ROS, ROS interacts with proteins, lipids and nucleotides in the cell structure. These pathways induce an apoptotic process $(8,9)$. Testis is a main organ for oxidative stress as a consequence of its large content material of polyunsaturated membrane lipids $(12,20)$. Thus, sensitivity of testis to oxidative agents such as CP is high. Therefore, use of antioxidants can prevent $\mathrm{CP}$-induced male infertility. In this study, we found that CP treatment caused increased oxidative stress and decreased antioxidant enzymes.

The antioxidant mechanism of ozone remains unknown. Once therapeutic ozone is administrated, ozone dissolves in the plasma and responds with polyunsaturated fatty acids and sulfhydryl groups. These reactions lead to the production of lipid hydroperoxides and hydrogen peroxides at low concentrations. Low-dose OT may act as cellular signal molecules and activates the cytoprotective pathways which increase the GSH synthesis and antioxidant capacity (11). Another antioxidant pathway of OT is inhibitory formation of xanthine oxidase thereby reducing the adenosine triphosphate depletion. Preserved adenosine induces vasodilation in the smooth muscle. It also inhibits the nuclear transcription factor kappa $B$, which is responsible for ozone, tissue damage, and inflammatory responses (26). Thus, ozone regulates inflammation and limits tissue injury. Ozone also has effects such as increasing blood flow to the tissues, activation of hypoxia-inducible factor-1a, vascular endothelial growth factor, activation of erythropoietin and glycolytic enzymes and increased $0_{2}$ delivery $(11,26)$.

Molecular mechanism of radio protective substances is essential for drug approval. To our knowledge, no study investigating the molecular mechanism of ozone in recovery or protection against $\mathrm{CP}$-induced testicular damage has been published.

\section{Study Limitations}

In our study, inadequate evaluation of tissue damage parameters and ROS is a limitation.

\section{Conclusion}

The current investigation demonstrated the fact that OT is shielding in CP-induced testicular destruction. OT might be effective in patients who go through CP chemotherapy. Further studies are needed to confirm our results and transition from experimental animal studies to clinical trials.

\section{Ethics}

Ethics Committee Approval: The approval was obtained from Bezmialem Vakıf University Ethics Committee (number: 24.11.2015/237).

Informed Consent: Experimental study.

Peer-review: Externally peer-reviewed.

\section{Authorship Contributions}

Surgical and Medical Practices: I.A., P.Y., Concept: I.A., Y.Ö.I., R.G.E., Design: I.A., Y.Ö.I., Data Collection or Processing: I.A., R.G.E., S.L.M., A.Ç., Y.E.A., H.K., Analysis or Interpretation: I.A., R.G.E., Y.E.A., M.B.S., A.Ç., S.L.M., H.K., Literature Search: I.A., Y.Ö.I., Y.E.A., A.Ç., S.L.M., M.B.S., H.K., Writing: I.A., Y.Ö.I., R.G.E., M.B.S.

Conflict of Interest: No conflict of interest was declared by the authors.

Financial Disclosure: The authors declared that this study received no financial support.

\section{References}

1. Lebwohl D, Canetta R. Clinical development of platinum complexes in cancer therapy: an historical perspective and an update. Eur J Cancer 1998;34:1522-1534

2. González $R$, Borrego $A$, Zamora $Z$, Romay $C$, Hernández $F$, Menéndez $S$, Montero T, Rojas E. Reversion by ozone treatment of acute nephrotoxicity induced by cisplatin in rats. Mediators Inflamm 2004;13:307-312.

3. Adejuwon SA, Femi-Akinlosotu OM, Omirinde JO. Cisplatin-induced testicular dysfunction and its amelioration by Launaea taraxacifolia leaf extract. Andrologia 2015;47:553-559.

4. Saral S, Ozcelik E, Cetin A, Saral O, Basak N, Aydın M, Ciftci 0. Protective role of Diospyros lotus on cisplatin-induced changes in sperm characteristics, testicular damage and oxidative stress in rats. Andrologia 2016;48:308-317.

5. Ahmed EA, Omar HM, elghaffar SKh, Ragb SM, Nasser AY. The antioxidant activity of vitamin C, DPPD and L-cysteine against Cisplatin-induced testicular oxidative damage in rats. Food Chem Toxicol 2011;49:1115-1121.

6. Silici S, Ekmekcioglu 0, Eraslan G, Demirtas A. Antioxidative effect of royal jelly in cisplatin-induced testes damage. Urology 2009;74:545-551. 
7. Colpi GM, Contalbi GF, Nerva F, Sagone P, Piediferro G. Testicular function following chemo-radiotherapy. Eur J Obstet Gynecol Reprod Biol 2004;5:113(Suppl 1):2-6.

8. Adaramoye $\mathrm{OA}$, Adedara IA, Farombi EO. Possible ameliorative effects of kolaviron against reproductive toxicity in sub-lethally whole body gammairradiated rats. Exp Toxicol Pathol 2012;64:379-385.

9. Ekici S, Doğan Ekici Al, Öztürk G, Benli Aksungar F, Sinanoğlu O, Turan G, Lüleci N. Comparison of melatonin and ozone in the prevention of reperfusion injury following unilateral testicular torsion in rats. Urology 2012;80:899-906

10. Mete F, Tarhan H, Celik O, Akarken I, Vural K, Ekin RG, Aydemir I, Ilbey YO. Comparison of intraperitoneal and intratesticular ozone therapy for the treatment of testicular ischemia-reperfusion injury in rats. Asian J Androl 2017;19:43-46.

11. Zanardi I, Borrelli E, Valacchi G, Travagli V, Bocci V. Ozone: A Multifaceted Molecule with Unexpected Therapeutic Activity. Curr Med Chem 2016;23:304-314

12. Beytur A, Ciftci O, Oguz F, Oguzturk H, Yilmaz F. Montelukast attenuates side effects of cisplatin including testicular, spermatological, and hormonal damage in male rats. Cancer Chemother Pharmacol 2012;69:207-213.

13. Johnsen SG. Testicular biopsy score count--a method for registration of spermatogenesis in human testes: normal values and results in 335 hypogonadal males. Hormones 1970;1:2-25.

14. Yagi K. Simple assay for the level of total lipid peroxides in serum or plasma. Methods Mol Biol 1998;108:101-106.

15. Sedlak J, Lindsay RH. Estimation of total, protein-bound, and nonprotein sulfhydryl groups in tissue with Ellman's reagent. Anal Biochem 1968;25:192-205.
16. Sun Y, Oberley LW, Li Y. A simple method for clinical assay of superoxide dismutase. Clin Chem 1988;34:497-500.

17. Aebi H. Catalase, In: Bergmeyer HU. Methods of enzymatic analysis, 2nd ed. New York, Elsevier, 1974, pp 673-677.

18. Paglia $D E$, Valentine $W N$. Studies on the quantitative and qualitative characterization of erythrocyte glutathione peroxidase. J Lab Clin Med 1967;70:158-169.

19. Kaya K, Ciftci O, Cetin A, Doğan H, Başak N. Hesperidin protects testicular and spermatological damages induced by cisplatin in rats. Andrologia 2015;47:793-800.

20. Ilbey YO, Ozbek E, Cekmen M, Simsek A, Otunctemur A, Somay A. Protective effect of curcumin in cisplatin-induced oxidative injury in rat testis: mitogen-activated protein kinase and nuclear factor-kappa B signaling pathways. Hum Reprod 2009;24:1717-1725.

21. Lirdi LC, Stumpp T, Sasso-Cerri E, Miraglia SM. Amifostine protective effect on cisplatin-treated rat testis. Anat Rec (Hoboken) 2008;291:797-808.

22. Boekelheide K. Mechanisms of toxic damage to spermatogenesis. J Natl Cancer Inst Monogr 2005;34:6-8.

23. Shen $\mathrm{HM}$, Chia $\mathrm{SE}$, Ong CN. Evaluation of oxidative DNA damage in human sperm and its association with male infertility. J Androl 1999;20:718-723.

24. Turner $\Pi$, Lysiak JJ. Oxidative stress: a common factor in testicular dysfunction. J Androl 2008;29:488-498.

25. Anand H, Misro MM, Sharma SB, Prakash S. Protective effects of Eugenia jambolana extract versus $\mathrm{N}$-acetyl cysteine against cisplatin-induced damage in rat testis. Andrologia 2015;47:194-208.

26. Salem EA, Salem NA, Hellstrom WJ. Therapeutic effect of ozone and rutin on adriamycin-induced testicular toxicity in an experimental rat model. Andrologia 2017;49:1-7. 